Family Medicine and Community Health

\title{
Response to letters by M. Jawad Hashim and Chuan Zou: Advancing curriculum development and medical education research
}

\author{
Margaret Dobson
}

To cite: Dobson M. Response to letters by M. Jawad Hashim and Chuan Zou: Advancing curriculum development and medical education research. Fam Med Com Health 2019;7:e000219. doi:10.1136/ fmch-2019-000219

Received 01 August 2019 Accepted 01 August 2019

\section{Linked}

http://dx.doi.org/10.1136/ fmch-2019-000216

- http://dx.doi.org/10.1136/ fmch-2019-000214

\section{Check for updates}

(C) Author(s) (or their employer(s)) 2019. Re-use permitted under CC BY-NC. No commercial re-use. See rights and permissions. Published by BMJ.

Department of Family Medicine, University of Michigan, Ann Arbor, Ml, United States

Correspondence to Dr Margaret Dobson; mlekande@med.umich.edu
In response to Hashim and Zou:

We appreciate the thoughtful read of our article $^{1}$ 'Curriculum development: a how to primer' and the commentaries about this topic by Drs Hashim and Zou. We thank Dr Hashim for bringing to light another specific type of teaching style, called here a mini-workshop, using some of the theory of the flipped classroom, which is ever more present in medical education. We validate that many aspects of medical education benefit from some hands-on practice, with pre-learning to be done either independently or as a group before the skillbased learning can take place. This would fit nicely with many other modalities one might consider during 'step 4: selecting teaching/ educational strategies' as articulated in our primer 'one should match the learner, teacher and material to one or more of the available teaching formats. ${ }^{1}$

Dr Zou's commentary reaches a bit further into the medical education research realm, which might or might not be a part of curriculum development. We felt this primer was intended to speak most directly to the development and implementation of a curriculum, with a nod towards evaluation, rather than representing a commentary on medical education research. We agree that there is certainly a need for more rigorous medical education research and discussion about methodology is important, but beyond the scope of our primer.

Funding The author has not declared a specific grant for this research from any funding agency in the public, commercial or not-for-profit sectors.

Competing interests None declared.

Patient consent for publication Not required.

Provenance and peer review Commissioned; internally peer reviewed.

Open access This is an open access article distributed in accordance with the Creative Commons Attribution Non Commercial (CC BY-NC 4.0) license, which permits others to distribute, remix, adapt, build upon this work non-commercially, and license their derivative works on different terms, provided the original work is properly cited, appropriate credit is given, any changes made indicated, and the use is non-commercial. See: http://creativecommons.org/licenses/by-nc/4.0/.

\section{REFERENCE}

1. Schneiderhan J, Guetterman TC, Dobson ML. Curriculum development: a how to primer. Fam Med Com Health 2019;7:e000046. 